\title{
タンパク質構造データマイニングのための三次元モチーフ辞書 の作成
}

\section{Construction of a Three-Dimensional Motif Dictionary for Protein Structural Data Mining}

\author{
加藤 博明 \\ Hiroaki Kato \\ hiro@cilab.tutkie.tut.ac.jp \\ 田所 哲男 \\ Tetsuo Tadokoro \\ 宮田 博之 \\ Hiroyuki Miyata \\ 近松 信一 \\ Shin-ichi Chikamatsu \\ 高橋 由雅 \\ Yoshimasa Takahashi \\ taka@mis.tutkie.tut.ac.jp \\ 阿部 英次 \\ (同上) \\ Hidetsugu Abe \\ abe@cilab.tutkie.tut.ac.jp
}

豊橋技術科学大学 知識情報工学系

Dept. Knowledge-based Information Engineering, Toyohashi University of Technology.

Keywords: protein motif, structural similarity, data mining, motif dictionary, PROSITE

\section{Summary}

With the rapidly increasing number of proteins of which three-dimensional (3D) structures are known, the protein structure database is one of the key elements in many attempts being made to derive the knowledge of structure-function relationships of proteins. In this work, the authors have developed a software tool to assist in constructing the 3D protein motif dictionary that is closely related to the PROSITE sequence motif database. In the PROSITE, a structural feature called motif is described by a sequence pattern of amino acid residues with the regular expression defined in the database. The present system allows us to automatically find the related sites for all the 3D protein structures taken from a protein structure database such as the Protein Data Bank (PDB), and to make a dictionary of the 3D motifs related to the PROSITE sequence motif patterns. A computational trial was carried out for a subset of the PDB's structure data file. The structural feature analysis resulted with the tool showed that there are many different 3D motif patterns but having a particular PROSITE sequence pattern. For this reason, the authors also tried to classify the 3D motif patterns into several groups on the basis of distance similarity matrix, and to determine a representative pattern for each group in preparing the dictionary. The usefulness of the additional approach for preparing the 3D motif dictionary is also discussed with an illustrative example.

\section{1.はじめに}

タンパク質は主たる遺伝情報の最終的な発現系とな る生体高分子であり, 光の三次元構造と機能との間には 密接な関係があることはよく知られている事実である . 特にモチーフと呼ばれるタンパク質構造中に特定の配置
で存在する局所構造特徵は, 遺伝子配列の中でもよく保 存されている部分であると考えられる[Branden 91, 中村 95] . 従って , タンパク質のモチーフ構造探索 , あるいは 広い意味での共通構造特徵の探索はタンパク質の構造機能解析だけでなく，遺伝情報解析においても極めて重 要な問題の一つである .一方 , ヒトゲノム計画の進展 , 並びにタンパク質構造決定技術の進歩に伴い立体構造の 
表 1 PROSITE 中の配列モチーフの例

\begin{tabular}{|c|c|c|}
\hline モチーフ & 種類 & パターン \\
\hline Kringle & ドメイン & [FY]-C-R-N-P- [ DNR]. \\
\hline $\begin{array}{l}\text { Zi nc fi nger } \\
\text { C2H2 }\end{array}$ & DNA 結合 & $\mathrm{C} \times \mathrm{x}(2,4)-\mathrm{C} \times(3)-[\mathrm{LI}$ VMFYWC] $-\mathrm{x}(\mathrm{8})-\mathrm{H} \times(3,5)-\mathrm{H}$. \\
\hline $\begin{array}{l}\text { Prot ei } n \\
\text { spl i ci ng }\end{array}$ & 翻訳後修飾 & [ DNEG] - x- [ LI VFA] - [ LI VMT] - [ LVAST] - H N [ STC] . \\
\hline EF- hand & カルシウム結合 & $\begin{array}{l}\text { D x- [ DNS] - \{ I LVFYY\} - [ DENSTG] - [ DNQGHRK] - }\{\text { GP }\} \text { - } \\
\text { [ LI VMC] - [ DENQSTAGC] - x ( 2) - [ DE] - [ LI VMFYW] }\end{array}$ \\
\hline
\end{tabular}

* パターン中で, $\mathrm{x}$ はとの位置で任意のアミノ酸と,[] は光の中のどれかのアミノ酸と， \{\} は关の中以外のいずれかのアミノ酸と対応することを炎れぞれ意味する . また , 要 素の後の（）内の数字は光の要素の繰り返しを表現し，例えば, $\mathrm{x}(\mathrm{n})$ は連続する $\mathrm{n}$ 個 の, $\mathrm{x}(\mathrm{n}, \mathrm{m})$ は $\mathrm{n}$ 個から $\mathrm{m}$ 個まで $(\mathrm{n}<\mathrm{m})$ の任意のアミノ酸とマッチすることを关れ 示す。

データは急速に増加しており, 光の構造データベースは タンパク質の構造と機能との関係解明など分子生物学上 の新たな知識獲得のための基本要素として产の重要性は ますます高まっている[Thornton 89, 金久 97] . しかし , タンパク質構造の巨大さや複雑さ, さらには近年の急激 なデー夕数の増大から, 手動によるモチーフの検索や光 の特徵解析はほとんど不可能となっている. そのため, これらのデータベースを有効に活用し，三次元構造特徵 の系統的な解析 (タンパク質構造データマイニング) を 行なうための方法論の確立, 並びに有効なコンピュータ ツールの開発が切望されている.

このため筆者らはこれまでに , グラフ論的な部分構造 検索技法[Kuhl 84, Bron 73]を基礎とした三次元モチーフ 構造検索アルゴリズム, さらには質問構造の設定を要求 しない複数タンパク質間の三次元共通構造特徵 (新規モ チーフ候補部位) の自動認識に向けての基本アルゴリズ ム, 並びに対応するシステムの開発を進めてきた[Kato 97, Kato 01] . 一方 , アミノ酸配列 (一次構造) レベルで の特徵解析は比較的古くからなされており, 配列アライ メント手法によるホモロジ - (相同性) 解析など樣々な

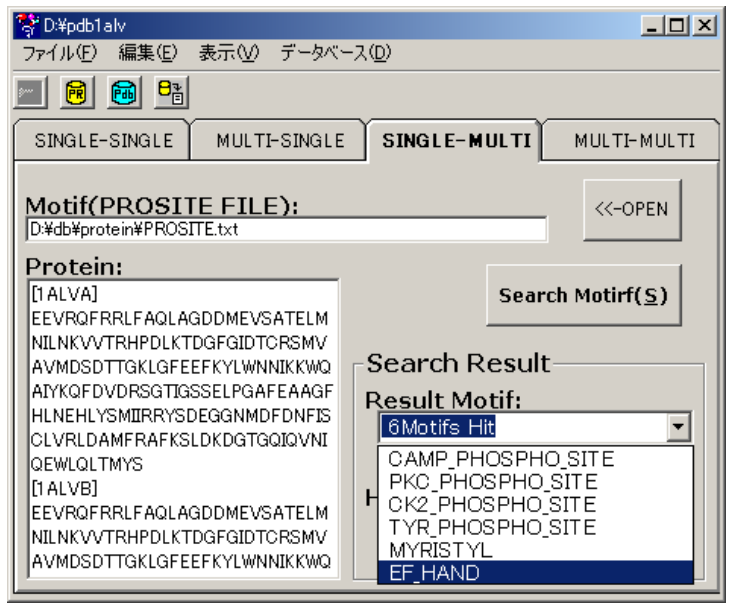

图 1 配列モチーフ検索プログラムの実行画面例
方法が提案されている[Gribskov 91] .このうち Bairoch は 配列レベルのモチーフ情報を文献等から広く収集して電 子化したモチーフ辞書 PROSITE を作成, 公開している [Bairoch 91] .PROSITE には酵素の活性部位やリガンド結 合部位の他 , タンパク質の細胞内の局在部位を決めるシ グナル配列などが収められている (表 1).

本研究では三次元分子構造特徵解析に基づく知識発 見の視点から，この既存の知識ベースともいえる PROSITE に登録されている配列モチーフパターンに注 目し，これに対応する三次元部分構造情報を網羅的に集 積するためのプログラムの開発を試みた . また, 集積し た対応三次元部分構造群を定量的に比較・分類し，各配 列モチーフに対応する代表三次元幾何パターンを決定す るための方法についても併せて検討した .

\section{2. 方法}

\section{1. 配列モチーフ検索}

PROSITEでは,配列モチーフを一種の正規表現を用い てパターンとして定義している.本研究では Protein Data Bank (PDB [Bernstein 77]) に登録された三次元構造既知 のタンパク質構造情報を対象に,PROSITEで定義された 配列モチーフ部位を検索し, 光の対応する三次元部分構 造をデータベースファイル (三次元モチーフ辞書) へ集 積する．ここでは，タンパク質の三次元構造情報は炎の 構成アミノ酸残基を単位として取り扱い, 各アミノ酸の アルファ炭素 $(\mathrm{C} \alpha)$ 原子の座標で代表して縮約表現するこ ととした . また処理の効率化のために, あらかじめ PDB ファイルから鎖単位でアミノ酸配列情報のみを抽出した ファイルと, 弚の三次元構造情報 (結合表形式) を抽出 したファイルの二つを作成し利用した .

本研究では, ユーザの目的によって対話的あるいはバ ッチ的な使い分けできるように, 次の四つの実行モード を定義し, Microsoft Windows 上で Visual C++ 6.0 及び 
VisualBasic 6.0 を用いて検索プログラムの実装を行なつ た .プログラムの実行画面例を図 1 に示す .

(1) ある一つのタンパク質の配列データを対象に，あ る一つの配列モチーフを指定し検索するモード (Single-Single)

(2) データベースに保存された複数のタンパク質の 配列データを対象に，ある一つの配列モチーフを 検索するモード (Multi-Single)

(3)一つの配列データを対象に, 複数の配列モチーフ を検索するモード (Single-Multi)

(4) 複数の配列データを対象に, 複数の配列モチーフ を検索するモード (Multi-Multi)

バッチモードでの検索でヒットしたタンパク質及び 対応部位情報は一時ファイル (MS-Access 形式のデータ ベースファイル) に登録され，必要に応じてここから対 応部位の一覧情報を記述したファイル (インデックスフ アイル (表 2)) や , 各対応部分構造の結合表ファイルを 取得することができる .ここで, インデックスファイル の一行目にはヘッダ情報としてモチーフの PROSITE 中 での ID 番号, 対応部位の数, 構成残基数 (サイズ) が 異なる部位の数, 及びその残基数を記述した . 例えば, 表 2 のケースでは, 表 1 に示した Zinc finger C2H2 モチ ーフ (ID: PS00028) に対応する部位が対象データベース 中で延べ 5 個検索されている . また , このモチーフは光 の柔軟なパターン定義により 残基数 21〜25 の複数の可 能なパターンに展開できるが ここでは，このうち 21,22 , 23 の 3 種類のパターンがヒットしたことを示している . また, 二行目以降は各対応部位について, シーケンシャ ル番号, PDB コード (必要に応じて鎖名を付加), サイ ズ，開始及び終了位置番号の情報を記した．例えば，表 2 の第 1 番目の対応部位は PDB コード $1 \mathrm{~A} 1 \mathrm{I}$ の A 鎖中に 存在する 21 残基で構成され, 光の配列上の位置は 137 番目の Cys から 157 番目の His まであることを示してい る.また，これらの得られた三次元部分構造をグラフィ ックス表示するためのインターフェースプログラムも併 せて実装し，結果を視覚的に検証できるよう工夫した． 表示には対応する PDB ファイルを参照し, 表示ツールと して MDL 社の Chemscape Chime プラグインを, 対応部 位の指定には RasMol スクリプト形式[Sayle 95]を用いた 作成したプログラムでは, 前述のインデックスファイル を入力し , 表示モデル等の指定を行ない, HTML ファイ ルの出力を行なう. 表示画面例を図 2 に，ユーザか指定 可能なメニューの一覧を以下に示す．

(1) 表示する三次元部分構造の指定

(2) 表示モードの指定

(全構造, 部分構造, 両方)

(3) 表示モデルの指定

(Ball\&Stick, Spacefill, Ribbons 等)

(4) 画面のサイズと分割数
表 2 インデックスファイルの例

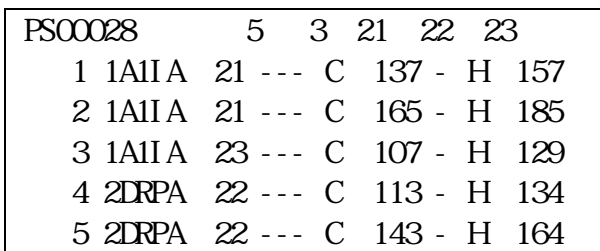

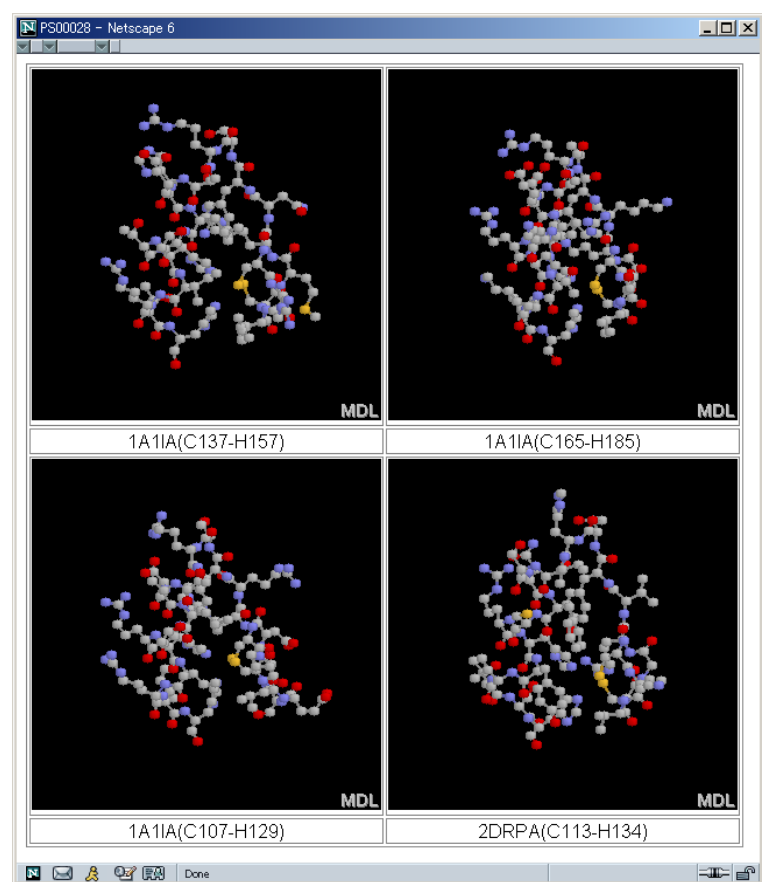

図 2 対応三次元部分構造のグラフィックス表示例

\section{2. 三次元部分構造の比較}

以上で集積された共通の配列パターンを持つ三次元 部分構造を検証した結果, 光の構造が大きく異なるもの がいつか存在した . 乥こで, 次にこれらの三次元部分 構造を定量的に比較 ·分類する方法について検討した。 前述のとおり, 本研究では三次元部分構造をアミノ酸残 基単位で取り扱い，光れ光れ C $\alpha$ 原子の座標で代表して 表現する .このようにして表現した二つの部分構造内の 対応する 2 点 ( $\mathrm{C} \alpha$ 原子) 間のユークリッド距離の平均誤 差（ここでは 100 倍して整数化した）を求め，これをこ れら二つの構造間の類似度 (相違度)の尺度と定義した，

(式 1).なお，PROSITE のパターン定義により，サイ ズ (構成アミノ酸残基数) が異なる部分構造が発生した 場合は, より小さい方の部分構造を基準とし, 配列順序 を維持したまま可能な組み合わせを全て列挙する. そとし て，光れ光れ上記の相違度の值を計算し，光のうちの最 小值をこれら二つの構造の相違度と定義した。

相違度 $(A, B)=\frac{\sum_{i=1}^{n} \sum_{j=1}^{n} \sqrt{\left(d_{A}(i, j)-d_{B}(i, j)\right)^{2}}}{n^{2}} \times 100$ 
ここで, $n$ は部分構造のサイズ (アミノ酸残基数) , $d_{A}(i, j), d_{B}(i, j)$ は光れ光れ部分構造 $\mathrm{A}, \mathrm{B}$ の $i$ 番目の 残基と $j$ 番目の残基の間の距離を表わす.

\section{3. 構造クラス分類}

ある一群のタンパク質部分構造 (共通の配列パターン を持つもの) を対象に，全てのペア間の相違度を求め， 相違度行列を生成する，例えば，表 3 は图 3 に示す四つ の部分構造に対する相違度行列の例である .ここである 闇值（例えば 100）を設定すれば，兴の閾值以内の構造 同士は同じクラスに属し，光れより大きいもの同士は 別々のクラスに属するものとみなすことができる .クラ スの選択に際しては, 行列の各行ごとに閾值以内となる 要素数を数え上げこれが最大となるもの（同数となる候 補が複数存在する場合は, 弚の相違度の和が最小となる もの) から優先して決定した

閾值の与え方により結果として得られる構造クラス の数やサイズは異なるが, 適切なクラス分けとなるよう な閾値をあらかじめ決定しておくことは難しい，光こで 本研究では, ある指定した範囲内で閾值を変化させ, 乥 の結果得られるクラスの情報を一覧表示するユーザイン ターフェース・プログラムを実装し, 対話的にクラス分 類を行なえるよう工夫した .

\section{4. 代表幾何パターンの決定}

以上によりいくつかの構造クラスが得られたら，次に 各クラスを代表する一つの三次元幾何パターンを決定す る.本研究では, 各部分構造について, 当該クラス中の 他の全ての部分構造との相違度の和を算出し, 光の合計 值が最小となるものを兴のクラスの代表パターン (すな わち,クラスの情報を反映する最も平均的な三次元構造) であると定義した . 表 3 の例の場合, $\mathrm{A} \cdot \mathrm{C} ・ \mathrm{D}$ の三つの 部分構造が属するクラス(1)の代表パターンは D , クラス (2)についてはB（自明）と決定される .

\section{3. 結果および考察}

PDB (Rel. \#89)から , Hobohm らの代表データセットの リスト[Hobohm 92]を参考に抽出したタンパク質テスト データセット (902 鎖) に対して, PROSITE (Rel. \#16.0) 中の全パターン（ただし，N-, C-両末端の終端指定子を 含む特殊なパターンは除外) 1,299 件を対象に Multi-Multi モードによる三次元構造モチーフ辞書の作成実験を試み た．弚の結果，少なくとも一つの三次元部分構造がヒッ 卜した配列モチーフは 464 件であった . 次に，このうち 対応部位数が $3 \sim 50$ のものについてクラス分類-代表パ ターン選出実験を引き続き行なった .

例えば EF-hand モチーフ(ID PS00018)に対応する部位 は延べ 12 個(一つのタンパク質構造中に複数のモチーフ
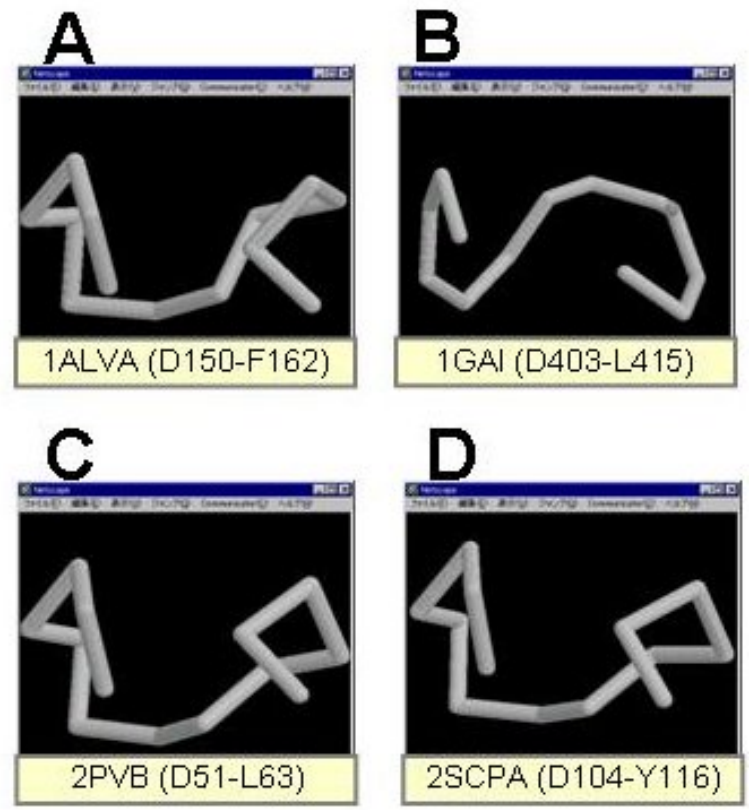

图 3 比較する四つの三次元部分構造 (EF-hand モチーフ対応部位の一例)

表 3 相違度行列による構造クラス分類結果例

\begin{tabular}{|c||c|c|c|c|}
\hline & A & B & C & D \\
\hline \hline A & 0 & 811 & 64 & 62 \\
\hline B & 811 & 0 & 802 & 786 \\
\hline C & 64 & 802 & 0 & 53 \\
\hline D & 62 & 786 & 53 & 0 \\
\hline \multicolumn{4}{|c|}{ * クラス(1) : A, C, D , クラス (2) : B }
\end{tabular}

(閾值 100 の場合)

部位がヒットするものも含む) 検索され (表 4)，閾值 100 を与えたときこれらが四つの構造クラスに，200 のとき 三つのクラスに关れ尓れ分類された．また，閾値 300 で は光の分類結果は 200 の場合と等価であり，次に变化が あったのは閾値 800 を与えたとき(2クラス)であった . また闇值 1000 で全体が一つのクラスとして認識された . ここでは，この閾値の間隔に注目し，3クラスに分類さ れたケースについてみると, 第1のクラスには 10 個の部 分構造が属し, 弚の代表パターンは 2SCPA (D104-Y116) と決定された . 一方，他の二つのクラスはいずれも属す る部分構造がーつのものであった .これら (1GAI (D403-L415) 及び 1GOH (D75-V87)) について調べると， 弚のタンパク質の機能や周辺環境(カルシウムイオンや， $\mathrm{E} ， \mathrm{~F}$ と呼ばれる前後の二つのへリックスの存在 [Branden 91, Kretsinger 80]) から，本モチーフに該当しな いノイズ成分であったことが確認できた . 
表 4 テストデータセットに対する EF-hand モチーフの検索結果

\begin{tabular}{|c|c|c|}
\hline PDB I D & 対応部位 & タンパク質 \\
\hline 1ALVA & D $150-F 162$ & Cal pai $n$ \\
\hline 1ALVA & D $180-\mathrm{L} 192$ & Cal pai $n$ \\
\hline 1GAl & D $403-$ L 415 & G ucoamyl ase- 471 \\
\hline $1 \mathrm{GOH}$ & D $75-\vee 87$ & Gal act ose oxi dase \\
\hline 1PSRA & D $62-\mathrm{F} 74$ & Psor i asi $n$ \\
\hline 1REC & $\mathrm{D} 110-\mathrm{V} 122$ & Recoverin \\
\hline 1SRA & D $257-$ W 269 & Spar c \\
\hline 2PVB & D $51-L \quad 63$ & Par val bumi $n$ \\
\hline 2PVB & D $90-F 102$ & Par val bumi $n$ \\
\hline 2SCPA & D $16-F 28$ & Sar copl asmi c cal ci um bi ndi ng pr ot ei $n$ \\
\hline 2SCPA & D $104-Y 116$ & Sar copl asmi c cal ci um bi ndi ng pr ot ei $n$ \\
\hline 2SCPA & D $138-F 150$ & Sar copl asmi c cal ci um bi ndi ng pr ot ei $n$ \\
\hline
\end{tabular}

\section{4. まとめと今後の課題}

本研究では PROSITE 中で定義された配列モチーフに 対応する三次元部分構造の集積・分類のためのプログラ ムを開発し, テストデータセットを用いた三次元モチー フ辞書の作成を試みた .特に，EF-hand モチーフの例で は構造クラス分類の結果, ノイズ成分を除去した主要ク ラスが生成され，弚の代表幾何パターンを得ることがで きた．これら分類結果は閾値の設定に大きく依存するた め, 合理的な閾値の決定に関して引き続き検討を行なっ ている.今後は, 得られた部分構造 (特に代表パターン) を基礎とし , 別途開発した三次元モチーフ検索プログラ ムを用いてタンパク質構造データマイニングのための三 次元構造特徵辞書の作成を進めるとともに計算機実験を 通じて钅の有用性を明らかにしたい .

\section{謝 辞}

本研究は文部科学省科学研究費補助金 - 特定領域研究 (B)「アクティブマイニング」のもとに行われたものであ ることを明記して謝意を表する．
[Bairoch 91] Bairoch, A.: PROSITE: a Dictionary of Sites and Patterns in Proteins, Nucleic Acids Res., Vol. 19, pp. 2241-2245 (1991).

[Bernstein 77] Bernstein, F. C., et al:: The Protein Data Bank: a Computer-based Archival File for Macromolecular Structures, J. Mol. Biol., Vol. 112, pp. 535-542 (1977).

[Branden 91] Branden, C. and Tooze, J.: Introduction to Protein Structure, Garland Publishing, New York (1991).

[Bron 73] Bron, C. and Kerbosch, J.: Finding All Cliques of an Undirected Graph, Comm. ACM, Vol. 16, pp. 575-577 (1973).

[Gribskov 91] Gribskov, M. and Devereux, J.: Sequence Analysis Primer, Stockton Press, New York (1991).

[Hobohm 92] Hobohm, U., Scharf, M., Schneider, R. and Sander, C.: Selection of Representative Protein Data Sets, Protein Sci., Vol. 1, pp. 409-417 (1992).

[金久 97] 金久實: ヒューマンゲノム計画，共立出版（1997）.

[Kato 97] Kato, H. and Takahashi, Y.: Three-Dimensional Structural Feature Search of Proteins, Bull. Chem. Soc. Jpn., Vol. 70, pp. 1523-1529 (1997).

[Kato 01] Kato, H. and Takahashi, Y.: Automated Identification of Three-Dimensional Common Structural Features of Proteins, J. Chem. Software, Vol. 7, pp. 161-170 (2001).

[Kretsinger 80] Kretsinger, R. H. : Structure and Evolution of Calcium-Modulated Proteins, CRC Crit. Rev. Biochem., Vol. 8, pp. 119-174 (1980).

[Kuhl 84] Kuhl, F. S., Crippen, G. M. and Friesen, D. K.: A Combinatorial Algorithm for Calculating Ligand Binding, J. Comput. Chem., Vol. 5, pp. 24-34 (1984).

[中村 95] 中村春木, 中井謙太：バイオテクノロジーのための コンピュータ入門，コロナ社 (1995).

[Sayle 95] Sayle, R. A. and Milner-White, E. J.: RASMOL: Biomolecular Graphics for All, Tends Biochem. Sci., Vol. 20, pp. 374-376 (1995).

[Thornton 89] Thornton, J. M. and Gardner, S. P.: Protein Motifs and Database Searching, Tends Biochem. Sci., Vol. 14, pp. 300-304 (1989).

〔担当委員 : 松本裕治〕 2002 年 3 月 1 日 受理 


\section{著 者 紹 介}

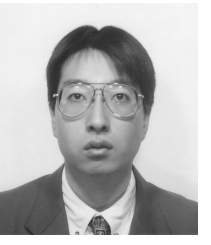

加藤 博明 (正会員)

1998 年豊橋技術科学大学大学院工学研究科 機能材料工学専攻博士課程修了. 現在豊橋 技術科学大学知識情報工学系助手.博士 (工 学). 分子情報工学, 特にタンパク質構造 情報処理に関する研究に従事 . 日本バイオ インフォマティクス学会, 日本コンピュー 夕化学会, 日本化学会 各会員.

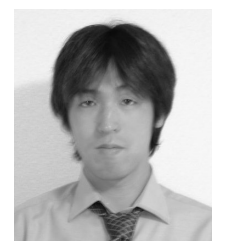

\section{田所 哲男}

2001 年豊橋技術科学大学大学院工学研究科 知識情報工学専攻修士課程修了. 同年 (株) 日立製作所入社 .

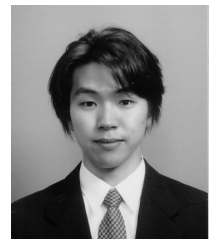

\section{宮田 博之}

2001 年豊橋技術科学大学工学部知識情報工 学課程卒業, 現在同大学大学院工学研究科 知識情報工学専攻修士課程在学中.

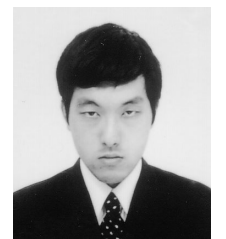

\section{近松 信一}

2002 年豊橋技術科学大学工学部知識情報工 学課程卒業, 現在同大学大学院工学研究科 知識情報工学専攻修士課程在学中.

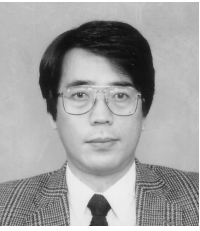

\section{高橋 由雅 (正会員)}

1978 年山梨大学大学院工学研究科発酵生産 学専攻修士課程修了. 現在豊橋技術科学大 学知識情報工学系教授. 農学博士. 分子情 報処理アルゴリズム，特に分子の構造類似 性の定量的評価手法に関する研究に従事. 日本バイオインフォマティクス学会, 米国化学会, 日本化学会, 日本薬学会 各会員.

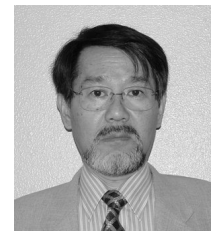

阿部 英次 (正会員)

1972 年東北大学大学院理学研究科化学専攻 博士課程修了. 現在豊橋技術科学大学知識 情報工学系教授. 化学情報学, 特に NMR スペクトルデータベース管理システムの構 築ならびに光の応用に関する研究に従事. 理学博士 . 情報処理学会, 米国化学会, 日 本化学会, 科学教育学会 各会員 